\title{
Row Arrangements of Maize and Soybean Intercrop on Silage Quality and Grain Yield
}

\author{
Vanderson Vieira Batista ${ }^{1}$, Paulo Fernando Adami ${ }^{2}$, Pedro Valério Dutra de Moraes ${ }^{1}$, Karine Fuschter Oligini ${ }^{3}$, \\ Cleverson Luiz Giacomel ${ }^{4} \&$ Lucas Link $^{1}$ \\ ${ }^{1}$ Post-graduate Program in Agroecosystems, Technologic University of Paraná, Dois Vizinhos, PR, Brazil \\ ${ }^{2}$ Post-graduate Program in Vegetable Production, Technologic University of Paraná, Dois Vizinhos, PR, Brazil \\ ${ }^{3}$ Post-graduate Program in Agronomy, Technologic University of Paraná, Pato Branco, PR, Brazil \\ ${ }^{4}$ Technologic University of Paraná, Dois Vizinhos, PR, Brazil \\ Correspondence: Vanderson Vieira Batista, Post-graduate Program in Agroecosystems, Technologic University of \\ Paraná, Dois Vizinhos, PR, Brazil. Tel: 55-469-9900-0618. E-mail: vandersonvbatista@hotmail.com
}

Received: October 13, $2018 \quad$ Accepted: November 14, $2018 \quad$ Online Published: January 15, 2019

doi:10.5539/jas.v11n2p286 URL: https://doi.org/10.5539/jas.v11n2p286

\begin{abstract}
The success of maize + soybean intercrop depends on the plant arrangement. An experiment was carried out to evaluate different row arrangements on intercrop forage yield, silage quality and maize grain yield in relation to maize as a sole crop. The experiment was set up with a randomized complete block design with eight row arrangements between maize and Soybean. Maize biomass yield among crop arrangements were similar, although, lower than the maize sole crop. On the other hand, these treatments showed higher soybean biomass yield, which in turn increased silage crude protein and crude protein yield per unit area. Maize thousand grain weight, grain yield per plant and per area was affected by the intercrop arrangements. The use of two corn rows + two soybean rows $(2 \mathrm{M}+2 \mathrm{~S}-30 \mathrm{~cm})$ and four corn rows + four soybean rows $(4 \mathrm{M}+4 \mathrm{~S}-30 \mathrm{~cm})$ showed higher crude protein yield per area associated with similar maize grain yield in relation to the sole maize crop. In conclusion, alternating four maize rows with four soybean rows was the optimum row ratio in maize + soybean intercrop, though this needs to be further confirmed by more trials.
\end{abstract}

Keywords: acid detergent fiber, animal feed, crude protein, dry mass, forage yield

\section{Introduction}

Maize and soybean are the most common grain crops in Brazil. Maize is the most used forage crop worldwide due to its many advantages such as high dry matter yield, high energy content, consistent-palatable feed, reduced total feed cost, rapid harvest and storability potential (Lempp et al., 2000), although, its low crude protein content may play a limitation on its use (Lempp et al., 2000; Evangelista et al., 2005; Oliveira et al., 2017).

Soybean also appears to be an option due to its great adaptability, yield potential and its high crude protein content (Kananji et al., 2013); Although fresh forage yield from soybean is low compared to maize, one of the major limitations to increase the use of soybeans for silage is the fact that when ensiled alone, it shows a bad fermentation process. It's use as intercrop with maize may improve soybean silage fermentation process as the soluble carbohydrate content and the higher maize DM content contribute to a good fermentation process.

Therefore, soybean intercropped with maize may be an option for improving silage quality (Lempp et al., 2000; Sánches et al., 2010; Batista et al., 2017) with the addition of nitrogen-rich soybean. According to Stella et al. (2016), maize silage presents $73 \mathrm{~g} \mathrm{~kg}^{-1}$ of crude protein and this value increased to 105 and $136 \mathrm{~g} \mathrm{~kg}^{-1}$ with the addition of 25 and $50 \%$ of soybean biomass into the silage, respectively. In this way, the use of soybean silage represents an alternative for increasing the protein content of the diet, thereby reducing production costs through reduced need for supplementation with protein concentrate.

Although not usually adopted in Brazil, maize + soybean intercrop may prove to be a more environmentally friendly sustainable method of producing silage and grain than the common maize monocrop system, due to better resources uses (Ren et al., 2016; Latati et al., 2016). There are many studies that shows greater land equivalent ratio (LER) of maize + soybean intercrop (Gao et al., 2010; Martin et al., 1998) in relation to 
conventional crop systems which gives a great incentive to intercrop adoption. Greater LER is mainly explained by higher radiation use efficiency (RUE) (Liu et al., 2017; Gao et al., 2010; Baghdadi et al., 2016) and better soil use (Baghdadi et al., 2016; Yang et al., 2017) through the stimulation of legume biological $\mathrm{N}_{2}$ fixation of intercrop versus monocrop.

Among intercrop management, crop row arrangement may be of greater significance as it affects the competitive dynamics between intercropped species and determines the yield of cereal-legume intercrops. In this sense, it is assumed that the higher the biomass production of soybean, the lower the grain yield of maize and vice versa, and that this effect may vary according to the arrangement of plants.

Also, when the objective of intercropping is for silage, the possible lower accumulation of maize biomass can be counterbalanced by the increase of the crude protein content of the silage. However, when maize is grown for grain, interspecific competition may affect yield potential to a point where it is not interesting to adopt this system. In fact, there is little data available and it is not usual to see farmers growing maize + soybean intercrop to harvest maize grain. Most of research shows that the yield of maize is reduced when intercropped with other species (Borghi \& Crusciol, 2007; Pereira et al., 2011; Silva et al., 2015). Being more specific, Alms (2015) studying the effect of voluntary soybean over maize reported grain yield losses around $30 \%$ with 37 plants $\mathrm{m}^{2}$ of soybeans.

Considering all these facts, the aim of this study was to determine the effects of maize + soybean intercrop row arrangement on (1) biomass production and silage quality, (2) maize grain yield potential, and (3) intercrops yield compared to maize monocrop, as maize and soybean are the two most important crops in Brazil.

\section{Material and Methods}

\subsection{Study Area}

Field experiment was carried out (2017/2018 summer growing season) at the Federal Technologic University of

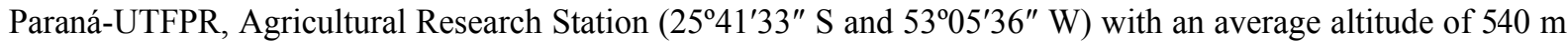
above sea level and a maximum slope of 3\%. According to the Köppen classification, the climate is Cfa (Alvares et al., 2013). Mean average rainfall is of 2,048 mm per year (IAPAR et al., 2018), which is well distributed along the year. The temperature and precipitation data observed during the study are shown in Figure 1.

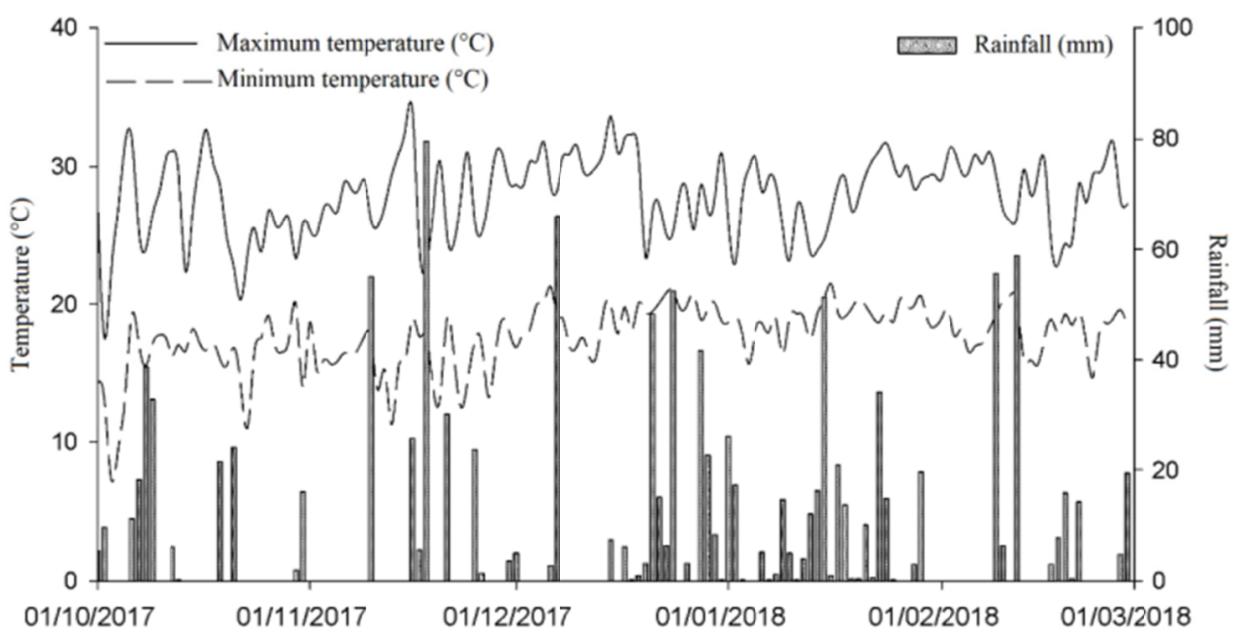

Figure 1. Maximum and minimum temperature $\left({ }^{\circ} \mathrm{C}\right)$ and rainfall $(\mathrm{mm})$ recorded by the INMET weather station of Dois Vizinhos-PR, during the experimental period

Source: INMET (2018).

Soil at the experimental site is classified as a Clayey Oxisol (Bhering et al., 2008). Soil chemical properties of the experimental site were determined in the 0.0-0.1 and 0.1-0.2 m layer, and the values are shown in Table 1. 
Table 1. Soil chemical analysis of the experimental site. UTFPR, Dois Vizinhos-PR, Brazil (2018)

\begin{tabular}{llllllrrr}
\hline Soil depth $(\mathrm{m})$ & $\mathrm{pH}$ & $\mathrm{OM}$ & $\mathrm{P}$ & $\mathrm{K}$ & $\mathrm{H}+\mathrm{Al}$ & $\mathrm{Ca}$ & $\mathrm{Mg}$ & $\mathrm{V}$ \\
\hline & $\mathrm{CaCl}_{2}$ & $\mathrm{~g} \mathrm{dm}^{-3}$ & $\mathrm{mg} \mathrm{dm}^{-3}$ & $----------------\mathrm{cmol}_{\mathrm{c}} \mathrm{dm}^{-3}$--------------- & $\%$ \\
$0-0.1$ & 5.40 & 44.23 & 36.65 & 0.28 & 2.95 & 4.40 & 1.50 & 67.69 \\
$0.1-0.2$ & 5.30 & 29.48 & 29.19 & 0.10 & 3.18 & 3.80 & 1.60 & 63.36 \\
\hline
\end{tabular}

Note. $\mathrm{OM}=$ Organic matter; $\mathrm{V}=$ base saturation.

\subsection{Experimental Design}

Experiment used a randomized complete block design with 9 treatments and four replications. Treatments were represented by different rows arrangements between maize + soybean intercrop and maize grown as a sole crop, as shown in Figure 2.
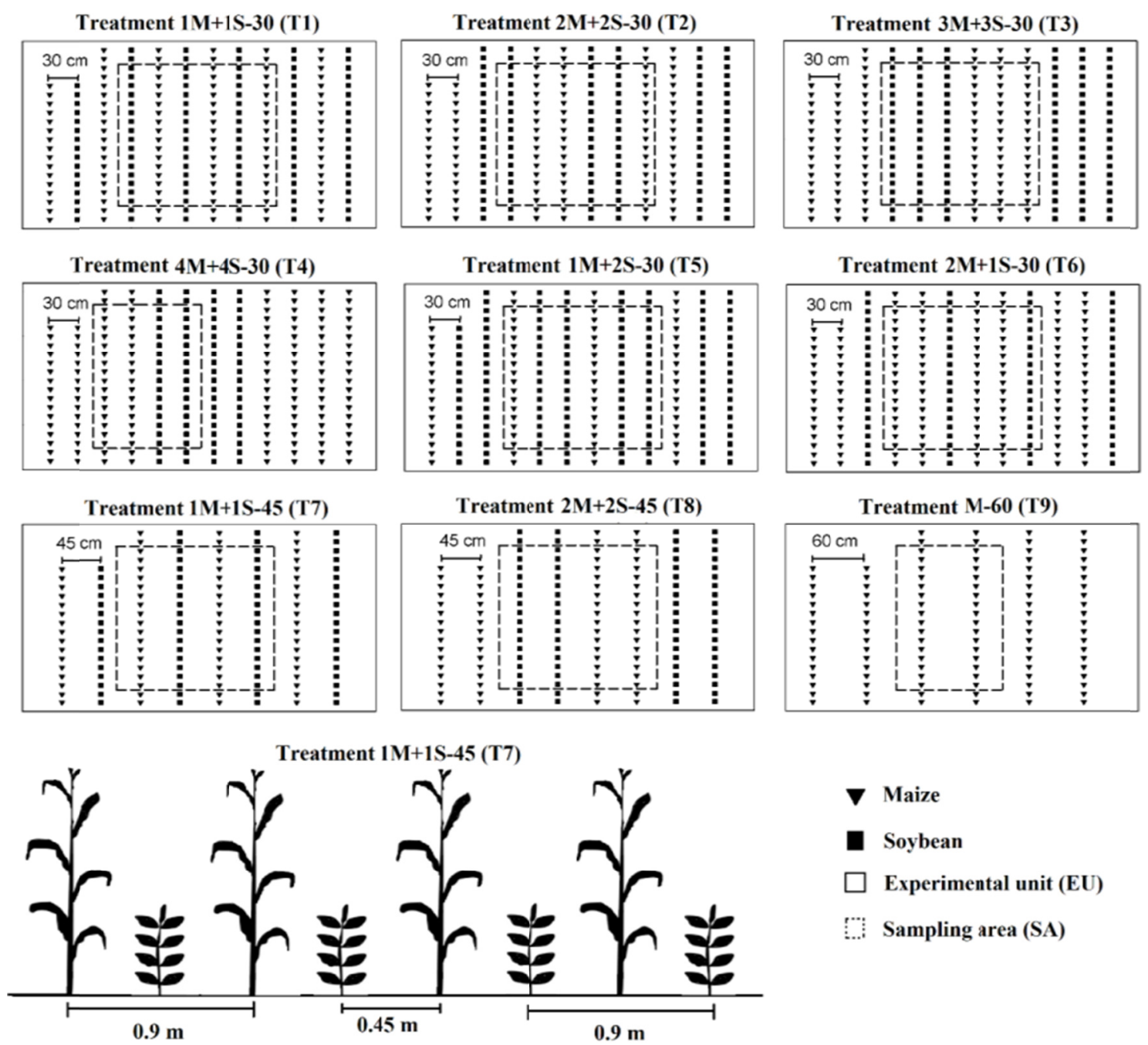

Figure 2. Maize + soybean intercrop row arrangement (treatments). UTFPR, Dois Vizinhos - PR, Brazil (2018). As an example, treatment 1 is represented by 1 row of maize +1 row of soybean spaced $30 \mathrm{~cm}$ between rows and so on to the other treatments. Treatment 9 is represented by maize monocrop with spacing of $60 \mathrm{~cm}$ between rows $(\mathrm{M}-60)$

The experimental plot size was of $72 \mathrm{~m}^{2}$ (3.6 m wide $\times 20 \mathrm{~m}$ long). From the main plots, half of it $(3.6 \times 10 \mathrm{~m})$ was used to determine silage yield and other half, its grain yield. 
Evaluations were carried out in the experimental unit (EU) considering a sampling area (SA), which was composed of the central rows of each EU, 5 meters long (Figure 2). As the numbers of treatments rows were different, the SA were constituted by $6 \mathrm{~m}^{2}$ for the treatments $4 \mathrm{M}+4 \mathrm{~S}-30$ and $\mathrm{M}-60$, and $9 \mathrm{~m}^{2}$ for the other treatments (Figure 2).

\subsection{Maize and Soybean Materials}

Maize hybrid 2B533 is recommended both for silage and grain production. It presents medium-sized plants, high grain yield, progressively responds to technology, presents high grain participation in dry matter, high total digestible nutrients (TDN), high digestibility and low neutral detergent fiber (NDF) and is recommended for whole plant or wet grain silage or grain product (Dow Agrosciences, 2018).

Soybean cultivar TMG7062-IPRO Intacta RR2 PROTM has been genetically modified and expresses a endotoxin that allows the soybean plant to protect itself against the main caterpillars species (PROTM) and tolerance to Phakosphera pakirizi, a rust disease, having also a maturity cycle classified as 6.2 which represents 125 to 135 days to relative maturity - RM) and seeding rate recommendation of 220 to 240 thousand seed ha ${ }^{-1}$ (Tropical Breeding and Genetics, 2017). Moreover, glyphosate-resistant soybean as a weed management tool has provided farmers with the opportunity and flexibility to manage a broad spectrum of weeds.

\subsection{Experiment Management}

Black oat (Avena strigosa) was used as prior crop and it was desiccated with glyphosate $\left(1.080 \mathrm{~g} \mathrm{ha}^{-1}\right.$ of active ingredient) 30 days before intercrop establishment. Maize + soybean intercrop was sown simultaneously on October $2^{\text {nd }}$ with the aid of a precision planter with seed disc distribution configured with smooth cuts disk, fertilizer plow rod type and seed furrow double disc type in a pantograph system. Row spacing was first configured to $30 \mathrm{~cm}$ and then changed to $45 \mathrm{~cm}$ to set up the treatments. It is important to highlight that most of farmers use $45 \mathrm{~cm}$ between crop rows, although, seeder rows spacing is easily adjustable and can be done by farmers.

Seed drill regulation was set up to sow 62,000 maize seeds $\mathrm{ha}^{-1}$ and soybean seed stand was a consequence of it. Maize seed discs had 28 holes, while soybean seed discs had 100 holes (a relation of 3.57 soybean seed to each maize seed sown).

Also, because the arrangements characterize different spacings between maize rows, soybean sowing density changed among the evaluated arrangements, as shown in Table 2.

Table 2. Distance between rows and seed distribution in maize + soybean intercropping in different row arrangements. UTFPR, Dois Vizinhos-PR, Brazil (2018)

\begin{tabular}{|c|c|c|c|c|c|c|}
\hline \multirow{3}{*}{ Treatments (arrangements) } & \multirow{2}{*}{\multicolumn{2}{|c|}{ Distance between rows $(\mathrm{cm})$}} & \multicolumn{4}{|c|}{ Total of seeds } \\
\hline & & & \multicolumn{2}{|c|}{ Maize } & \multicolumn{2}{|c|}{ Soybean } \\
\hline & Maize & Soybean & Linear meter & $\mathrm{ha}^{-1}$ & Linear meter & $\mathrm{ha}^{-1}$ \\
\hline $1 \mathrm{M}+1 \mathrm{~S}-30$ & 60 & 60 & 3.72 & 62,000 & 13.29 & 221.429 \\
\hline $2 \mathrm{M}+2 \mathrm{~S}-30$ & 60 & 60 & 3.72 & 62,000 & 13.29 & 221.429 \\
\hline $3 \mathrm{M}+3 \mathrm{~S}-30$ & 60 & 60 & 3.72 & 62,000 & 13.29 & 221.429 \\
\hline $4 \mathrm{M}+4 \mathrm{~S}-30$ & 60 & 60 & 3.72 & 62,000 & 13.29 & 221.429 \\
\hline $1 \mathrm{M}+2 \mathrm{~S}-30$ & 90 & 45 & 5.58 & 62,000 & 19.93 & 442.857 \\
\hline $2 \mathrm{M}+1 \mathrm{~S}-30$ & 45 & 90 & 2.79 & 62,000 & 9.96 & 110.714 \\
\hline $1 \mathrm{M}+1 \mathrm{~S}-45$ & 90 & 90 & 5.58 & 62,000 & 19.93 & 221.429 \\
\hline $2 \mathrm{M}+2 \mathrm{~S}-45$ & 90 & 90 & 5.58 & 62,000 & 19.93 & 221.429 \\
\hline M-60 & 60 & - & 3.72 & 62,000 & - & - \\
\hline
\end{tabular}

At sowing, fertilization was done for both species adding $450 \mathrm{~kg} \mathrm{ha}^{-1}$, of chemical fertilizer 5-20-10 $\left(\mathrm{N}-\mathrm{P}_{2} \mathrm{O}_{2}-\mathrm{K}_{2} \mathrm{O}\right)$. Nitrogen $(\mathrm{N})$ was applied as urea $(45 \%$ of $\mathrm{N})$ at the rate of $180 \mathrm{~kg} \mathrm{~N}$ of ha ${ }^{-1}$. Half of the $\mathrm{N}$ dose was applied at V4 (three weeks after sowing) and the remaining half at V8, all by side placement manually along the rows. Insecticide imidacloprid + beta-cyfluthrin at the dose of $1 \mathrm{~L} \mathrm{ha}^{-1}$ was applied, shortly after maize emergence to control stink bug (Dichelops melacanthus). Weed control was achieved by applying glyphosate $\left(1.2 \mathrm{~g} \mathrm{a}\right.$ i. $\left.\mathrm{ha}^{-1}\right)$ on maize at $\mathrm{V} 3$ stage. Fungicide application was done at maize R2 stage with a systemic ready mixture product containing estrobilurina + pirazol carboxamida at a commercial dose of $300 \mathrm{~g} \mathrm{ha}^{-1}$. Along with 
the fungicide, vegetable oil was added at a dose of $0.5 \mathrm{~L} \mathrm{ha}^{-1}$ and spray volume of $160 \mathrm{~L} \mathrm{ha}^{-1}$ applied with a self-propelled sprayer.

\subsection{Evaluations}

\subsubsection{Stand of Plants and Morphological Characteristics of Crops}

Maize (MPS) and soybean (SPS) plants stand were determined at the maize ensiling point (01/30/2018-120 days after its emergency), by counting the number of plants present in each EU and extrapolating to hectare (plants $\left.\mathrm{ha}^{-1}\right)$.

Soybean number of pods per plant (NPP) were evaluated in ten randomized plants per EU. Also, ten maize plants per plot were evaluated for determining the stem diameter (SD-between the second and third nodes with the aid of a caliper), spike height insertion (SHI - distance between soil level and the insertion of the main maize spike) plant height ( $\mathrm{PH}$ - distance from the soil to the most distant point of the plants, and the values were obtained with a tape measure) being the values expressed in centimeters. The mean values obtained at each EU were considered for the data analysis.

\subsubsection{Crop Dry Mass and Silage Biomass Yield}

Silage harvesting was performed when maize had reached $2 / 3$ milk line stage, which happened 120 days after its emergence. At that point, soybean cultivar was at the 5.5 phenological stage.

Plants from the SA were harvested by hand cutting the plant $25 \mathrm{~cm}$ above the soil surface. They were weighed to determine maize (MGBY) and soybean (SGBY) green biomass yield. Then, plant samples of both crops of each SA were ground separately on a forage harvester coupled to a tractor with an average particle size of 0.5 to 1.5 $\mathrm{cm}$. In addition, whole plant samples were weighed fresh and sub-samples $(300 \mathrm{~g})$ were placed in paper bags, weighed and oven-dried at $65^{\circ} \mathrm{C}$ for at least 72 hours until constant weight to determine its dry matter content.

Forage DM yield was calculated from the fresh and dry weights of respective components listed above to determine maize and soybean dry matter yield (MDMY and SDMY) and its sum resulted in the total dry matter yield $($ TDMY $=$ MDMY + SDMY $)\left(\mathrm{Kg} \mathrm{ha}^{-1}\right)$.

\subsubsection{Silage Chemical-Bromatological Traits and Digestibility}

Samples of maize and soybean plants that had previously been collected and ground separately were grouped into the corresponding experimental units. Amount of maize and soybean were taken, relating to the proportion of the field biomass production between maize and soybean. This biomass was mixed for total homogenization and samples of $3 \mathrm{~kg}$ was packed compactly into Laboratory silos made of PVC pipes, measuring $100 \mathrm{~mm}$ in diameter, $600 \mathrm{~mm}$ in length, with average density of $600 \mathrm{~kg} \mathrm{~m}^{-3}$. The silos were sealed at the time of ensiling, with PVC caps fitted with 'Bunsen' type valves. The silos were opened after 60 days of ensiling.

Upon the opening of the silos, the material was homogenized and extracted for further analysis. At the time, $\mathrm{pH}$ determination was carried out using a $\mathrm{pH}$ meter in accordance with the methodology described by Silva and Queiroz (2002). Samples collected (300 g) after opening the silos were placed in paper bags, weighed and oven-dried at $55{ }^{\circ} \mathrm{C}$ for at least 72 hours until constant weight to determine its dry matter content. The pre-dried samples were ground in a 'Wiley' type mill with a $1 \mathrm{~mm}$ mesh sieve, and the samples taken to the Bromatological Analysis Laboratory of the UTFPR.

Further analysis of dry matter, ashes (\%) (Silva \& Queiroz, 2002), neutral detergent fiber (NDF), acid detergent fiber (ADF) (\%) were determined by the methodology described in the Ankon (2009) manual. TDN $=87.84-$ $(0.7 \times \mathrm{ADF})$ was used to estimate the total digestible nutrients $(\mathrm{TDN})$. Silage crude protein $(\mathrm{SCP})\left(\mathrm{g} \mathrm{kg}^{-1}\right)$ analysis was performed by quantifying the $\mathrm{N}$ present in the samples, with the total $\mathrm{N}$ being determined in Kjeldhal semi-micro steam distillation methodology (Tedesco et al., 1995). By multiplying SCP values by each silage component dry matter yield and from its sum, total silage crude protein yield (TCPY) $\left(\mathrm{Kg} \mathrm{ha}^{-1}\right)$ was determined.

\subsubsection{Maize Grain Yield Components and Total Yield}

Grain harvesting was carried out on March 3, 2018 (152 days after sowing) with mean moisture of 22\%. To determine maize yield components, 10 cobs per plot were evaluated to determine the number of grains per row (NGR-grain smaller than $1 / 2$ normal grain was not considered) and the number of rows (NR) per cob. In addition, the weight of thousand grains was assessed by manual counting 5 samples of 100 grains, weighing and corrected for moisture content of $13 \%$, with extrapolation to thousand-grain weight. Number of grain per spike (NGE), was determined considering the NGR and NR $(\mathrm{NGE}=\mathrm{NGR} \times \mathrm{NR})$. For the statistical analyzes, the mean values observed in each SA were used. 
Maize yield was assessed by harvesting the spikes of the SA and passing them through a stationary small-plot maize sheller. Maize grain yields were adjusted to a moisture content of $13 \mathrm{~g} \mathrm{~kg}^{-1}$. Grain yield per plant was also evaluated by dividing total yield to the maize population.

\subsection{Statistical Analysis}

All data were submitted to analysis of variance (Anova), and when it presented significance $(\mathrm{P}<0.05)$, mean was compared through the Tukey test. Intercrop results were compared with the maize monocrop data through the contrast " $t$ " test. For analysis of data, Sisvar 5.6 (Ferreira, 2008) software was used.

\section{Results and Discussion}

\subsection{Stand de Plants and Features Morphological Traits}

Final stand of maize plants (FMP) was not influenced by the different row arrangements (treatments), showing a mean of 58,159 plants $\mathrm{ha}^{-1}$ (Table 3). This result supports the data, since the objective was to have a similar maize population for all the evaluated treatments. Batista et al. (2018) reported a difference of 9.1\% between sowing density $\left(60,000\right.$ seeds $\left.\mathrm{ha}^{-1}\right)$ and the mean of the final population $\left(54,513\right.$ plants ha $\left.{ }^{-1}\right)$, which was higher than that observed in the present study $\left(62,000 \mathrm{ha}^{-1}-58,159\right.$ plants ha $\left.{ }^{-1}\right)$. These results, combined with the analysis of the " $t$ " test, show that soybean intercropped with maize did not affect FMP values, since maize monocrop showed similar FMP when compared to the intercropping treatments (Table 3).

Table 3. Final plant population and morphological traits of maize + soybean intercrop at the plant row arrangements. UTFPR, Dois Vizinhos-PR, Brazil (2018)

\begin{tabular}{|c|c|c|c|c|c|c|}
\hline Treatments (arrangements) & FMP & FSP & SD & SHI & MPH & NPSP \\
\hline $1 \mathrm{M}+1 \mathrm{~S}-30$ & $60,000.00^{\text {ns }}$ & $139,166.70 \mathrm{~b}$ & $2.35 \mathrm{a}^{\mathrm{ns}}$ & $134.20 \mathrm{a}^{*}$ & $266.75 \mathrm{a}^{\mathrm{ns}}$ & $10.25 \mathrm{~b}$ \\
\hline $2 \mathrm{M}+2 \mathrm{~S}-30$ & $56,250.00^{\mathrm{ns}}$ & $118,750.00 \mathrm{~b}$ & $2.30 \mathrm{a}^{\mathrm{ns}}$ & $136.00 \mathrm{a}^{*}$ & $268.15 \mathrm{a}^{\mathrm{ns}}$ & $14.85 \mathrm{~b}$ \\
\hline $3 \mathrm{M}+3 \mathrm{~S}-30$ & $58,611.11^{\mathrm{ns}}$ & $125,277.80 \mathrm{~b}$ & $2.15 \mathrm{~b}^{*}$ & $127.33 b^{\text {ns }}$ & $259.38 \mathrm{~b}^{\mathrm{ns}}$ & $15.03 \mathrm{~b}$ \\
\hline $4 \mathrm{M}+4 \mathrm{~S}-30$ & $57,083.33^{\text {ns }}$ & $117,083.30 \mathrm{~b}$ & $2.26 \mathrm{a}^{*}$ & $125.48 \mathrm{~b}^{\mathrm{ns}}$ & $257.70 \mathrm{~b}^{\mathrm{ns}}$ & $29.63 \mathrm{a}$ \\
\hline $1 \mathrm{M}+2 \mathrm{~S}-30$ & $56,111.11^{\mathrm{ns}}$ & $241,111.10 \mathrm{a}$ & $2.12 b^{*}$ & $132.70 \mathrm{a}^{*}$ & $267.35 \mathrm{a}^{\mathrm{ns}}$ & $11.35 \mathrm{~b}$ \\
\hline $2 \mathrm{M}+1 \mathrm{~S}-30$ & $60,000.00^{\mathrm{ns}}$ & $82,222.22 \mathrm{c}$ & $2.22 \mathrm{a}^{*}$ & $134.00 \mathrm{a}^{*}$ & $266.75 \mathrm{a}^{\mathrm{ns}}$ & $8.15 \mathrm{~b}$ \\
\hline $1 \mathrm{M}+1 \mathrm{~S}-45$ & $59,444.44^{\mathrm{ns}}$ & $159,086.10 \mathrm{~b}$ & $2.06 b^{*}$ & $136.15 \mathrm{a}^{*}$ & $268.28 \mathrm{a}^{\mathrm{ns}}$ & $12.65 \mathrm{~b}$ \\
\hline $2 \mathrm{M}+2 \mathrm{~S}-45$ & $57,777.78^{\text {ns }}$ & $141,944.40 \mathrm{~b}$ & $2.03 \mathrm{~b}^{*}$ & $122.18 b^{\mathrm{ns}}$ & $252.63 \mathrm{~b}^{\mathrm{ns}}$ & $13.60 \mathrm{~b}$ \\
\hline Mean & $58,159.72$ & $140,580.20$ & 2.18 & 131.00 & 263.37 & 14.44 \\
\hline $\mathrm{P}$ & 0.6360 & 0.0000 & 0.0063 & 0.0165 & 0.0372 & 0.0001 \\
\hline $\mathrm{CV}$ & 6.34 & 16.30 & 5.41 & 4.54 & 2.80 & 22.18 \\
\hline M-60 & $57,500.00$ & $* *$ & 2.43 & 124.13 & 258.70 & $* *$ \\
\hline
\end{tabular}

Note. ANOVA: $\mathrm{P}>0.05=$ not significant; $0.05 \geq \mathrm{P} \geq 0.01=$ significant at $5 \% ; \mathrm{P}<0.01=$ significant at $1 \%$. Tukey Test: In each column, averages followed by different lowercase letter differ by the Tukey test in $5 \%$ of probability. Test $\mathrm{T}:{ }^{\mathrm{ns}}=$ Nonsignificant; $*=$ Significant at the $\mathrm{p} \leq 0.05$ level; $* *=$ The 0 (zero) values to the M-60, test T is not applied. FSC $=$ final stand of maize plants (plants ha ${ }^{-1}$ ); FSP $=$ final stand of soybean plants $\left(\right.$ plants $\left.\mathrm{ha}^{-1}\right) ; \mathrm{SD}=$ stem diameter $(\mathrm{cm}) ; \mathrm{SHI}=$ spike height insertion $(\mathrm{cm}) ; \mathrm{MPH}=$ maize plant height $(\mathrm{cm})$; NPSP $=$ Number of pods per soybean plant.

Final stand of soybean plants (FSS) was a consequence of maize seeding rate, resulting in higher values to the $1 \mathrm{M}+2 \mathrm{~S}-30\left(241,111\right.$ plants $\left.\mathrm{ha}^{-1}\right)$ and lower values to the $2 \mathrm{M}+1 \mathrm{~S}-30\left(82,222\right.$ plants $\left.\mathrm{ha}^{-1}\right)$ arrangement, with intermediate values to the other arrangements (Table 3).

There was a great difference between sowing density (Table 2) and the FSP values (Table 3), at the $1 \mathrm{M}+2 \mathrm{~S}-30$ treatment, which ranged from 442,857 to 241,111 plants $\mathrm{ha}^{-1}$, with a reduction of $45.8 \%$. Lempp et al. (2000) point out that one of the difficulties in maize + soybean intercrops is to obtain a high number of soybean plants per linear meter. Liu et al. (2017) emphasize in their studies that in maize + soybean intercrop, soybean crop is the most affected species due to maize competition potential, requiring good arrangement of plants/rows/density to reach system success, otherwise, soybean may show low dry mass accumulation. Moreover, higher density of plant per linear meter may result in self-thinning process, where plants with lower vigor die. In this context, the use of soybean seed disc with a lower number of holes (64 as an example) may be an option to reduce seed expenses at the $1 \mathrm{M}+2 \mathrm{~S}-30$ treatment. It is worth commenting that usually, one of the problems/difficulties in 
adopting legumes is the seed cost, although, the cost of soybean seeds are very low once farmers can produce and use his own soybean seeds/grains in the corn intercrop.

Maize plants morphological traits (SD, SHI, MPH) differed among treatments, where the arrangements $1 \mathrm{M}+1 \mathrm{~S}-30,2 \mathrm{M}+2 \mathrm{~S}-30,4 \mathrm{M}+4 \mathrm{~S}-30$ and $2 \mathrm{M}+1 \mathrm{~S}-30$ showed ticker stem diameter (SD) and the arrangements $1 \mathrm{M}+1 \mathrm{~S}-30,2 \mathrm{M}+2 \mathrm{~S}-30,1 \mathrm{M}+2 \mathrm{~S}-30,2 \mathrm{M}+1 \mathrm{~S}-30$ and $1 \mathrm{M}+1 \mathrm{~S}-45$ stood out with greater SHI and MPH. It was also noticed that most of the arrangements $(1 \mathrm{M}+1 \mathrm{~S}-30,2 \mathrm{M}+2 \mathrm{~S}-30,1 \mathrm{M}+2 \mathrm{~S}-30,2 \mathrm{M}+1 \mathrm{~S}-30$ and $1 \mathrm{M}+1 \mathrm{~S}-45)$ showed higher spike insertion height when compared to the maize monocrop, although, final maize plant height was similar between arrangements (Table 3).

Paz et al. (2017) did not observe interference in the maize spike insertion and plant height when cultivated with different legumes as intercrops. Santos et al. (2017) also reported similar values of spike insertion and plant height, for the maize intercropped with fodder. Stacciarini et al. (2010) and Ferreira et al. (2015) observed that row spacing and plant density affect intercrop competition and may influence stem diameter in maize crop, but with no effect on plant height and spike insertion height. Taller plants represent better development as a result of lower intercrop interference, or in other words, row arrangements with taller plants fits better for intercrop systems.

Maize plant morphological differences among row arrangements and/or in relation to the maize monocrop reported in Table 3 do not present a standard, although, lower row spacing and higher plant density per linear meter tends to increase plant competition and as a morphological change, plants tend to grow higher. This fact explains part of the differences noticed among arrangements.

Regarding the number of pods per plant, 4M+4S-30 arrangement stood out with 29.6 pods per plant, differing over other treatments (Table 3). This trait is important as soybean grain may increase the fodder quality. Since most of the protein in the soybean plant will have been translocated to the seeds at harvest, the higher number of soybean pods may increase silage protein concentration. Soybeans contains about 17 to $18 \%$ of oil and 35 to $37 \%$ of crude protein of high biological value, with a composition in essential amino acids favorable to animal feed and therefore is a good alternative protein feed (Mendes et al., 2004). It is possible to infer that greater distance between rows is advantageous as this arrangement allowed better photosynthetic radiation incident on the soybean plants, allowing a greater pod number. According to Liu et al. (2017), the lack of photosynthetic radiation intercepted by the soybean crop in maize + soybean intercrop, results in a significant reduction in plant development and pods differentiation.

\subsection{Crops Silage Biomass, Dry Mass and Biomass Yield}

Silage dry mass is a very important parameter as it directly affects silage fermentation (Cruz et al., 2001). Regarding to the dry mass of the crops (MSDM=Maize silage dry mass and SSDM=Soybean silage dry mass) at the time of ensiling, a statistical difference was observed in both crops (Table 4). Data analysis divided the MDM of the arrangements into two groups, the first with higher values formed by treatments $1 \mathrm{M}+1 \mathrm{~S}-30$, $2 \mathrm{M}+2 \mathrm{~S}-30,4 \mathrm{M}+4 \mathrm{~S}-30,1 \mathrm{M}+1 \mathrm{~S}-45$ and $2 \mathrm{M}+2 \mathrm{~S}-45$ and the second with lower values composed of $3 \mathrm{M}+3 \mathrm{~S}-30$, $1 \mathrm{M}+2 \mathrm{~S}-30$ and $2 \mathrm{M}+1 \mathrm{~S}-30$. When compared to the maize monocrop, there were no differences to the maize silage dry mass (Table 4). As for the MDM, the evaluated arrangements were also divided into two groups for the SDM, with the highest values obtained in the $2 \mathrm{M}+2 \mathrm{~S}-30,4 \mathrm{M}+4 \mathrm{~S}-30,2 \mathrm{M}+1 \mathrm{~S}-30$ and $2 \mathrm{M}+2 \mathrm{~S}-45$ (Table 4). 
Table 4. Crops silage biomass dry mass and silage biomass dry matter yield at the maize + soybean intercrop row arrangements. UTFPR, Dois Vizinhos-PR, Brazil (2018)

\begin{tabular}{llllll}
\hline Treatments (arrangements) & MSDM & SSDM & SBY & MBY & TBY \\
\hline $1 \mathrm{M}+1 \mathrm{~S}-30$ & $35.41 \mathrm{a}^{\mathrm{ns}}$ & $23.27 \mathrm{~b}$ & $1,773.78 \mathrm{~b}$ & $22,267.33^{\mathrm{ns}}$ & $24,041.11^{\mathrm{ns}}$ \\
$2 \mathrm{M}+2 \mathrm{~S}-30$ & $35.90 \mathrm{a}^{\mathrm{ns}}$ & $25.23 \mathrm{a}$ & $2,564.87 \mathrm{a}$ & $22,318.78^{\mathrm{ns}}$ & $24,883.65^{\mathrm{ns}}$ \\
$3 \mathrm{M}+3 \mathrm{~S}-30$ & $33.90 \mathrm{~b}^{\mathrm{ns}}$ & $24.26 \mathrm{~b}$ & $2,203.39 \mathrm{~b}$ & $20,461.90^{*}$ & $22,665.27^{\mathrm{ns}}$ \\
$4 \mathrm{M}+4 \mathrm{~S}-30$ & $37.43 \mathrm{a}^{\mathrm{ns}}$ & $26.14 \mathrm{a}$ & $3,045.35 \mathrm{a}$ & $21,948.45^{\mathrm{ns}}$ & $24,993.79^{\mathrm{ns}}$ \\
$1 \mathrm{M}+2 \mathrm{~S}-30$ & $33.03 \mathrm{~b}^{\mathrm{ns}}$ & $23.22 \mathrm{~b}$ & $2,742.61 \mathrm{a}$ & $20,187.63^{*}$ & $22,930.25^{\mathrm{ns}}$ \\
$2 \mathrm{M}+1 \mathrm{~S}-30$ & $33.22 \mathrm{~b}^{\mathrm{ns}}$ & $26.57 \mathrm{a}$ & $1,354.60 \mathrm{c}$ & $20,787.93^{\mathrm{ns}}$ & $22,142.53^{\mathrm{ns}}$ \\
$1 \mathrm{M}+1 \mathrm{~S}-45$ & $35.86 \mathrm{a}^{\mathrm{ns}}$ & $23.23 \mathrm{~b}$ & $1,796.17 \mathrm{~b}$ & $21,348.88^{\mathrm{ns}}$ & $23,145.05^{\mathrm{ns}}$ \\
$2 \mathrm{M}+2 \mathrm{~S}-45$ & $37.69 \mathrm{a}^{\mathrm{ns}}$ & $26.97 \mathrm{a}$ & $2,701.51 \mathrm{a}$ & $21,624.57^{\mathrm{ns}}$ & $24,326.09^{\mathrm{ns}}$ \\
$\mathrm{M}$ Mean & 35.30 & 24.86 & $2,272.79$ & $21,368.18$ & $23,640.97$ \\
$\mathrm{P}$ & 0.0081 & 0.0014 & 0.0000 & 0.5925 & 0.2896 \\
$\mathrm{CV}$ & 5.31 & 5.69 & 14.61 & 8.53 & 7.89 \\
$\mathrm{M}-60$ & 35.55 & $* *$ & $* *$ & $23,239.37$ & $23,239.37$
\end{tabular}

Note. ANOVA: $\mathrm{P}>0.05=$ not significant; $0.05 \geq \mathrm{P} \geq 0.01=$ significant at $5 \% ; \mathrm{P}<0.01=$ significant at $1 \%$. Tukey Test: In each column, averages followed by different lowercase letter differ in 5\% of probability. Test T: ${ }^{\mathrm{ns}}=$ Nonsignificant; $*=$ Significant at the $\mathrm{p} \leq 0.05$ level; $* *=$ The 0 (zero) values to the M- 60 , test $\mathrm{T}$ is not applied. MSDM = Maize dry mass (\%); SDM = Soybean dry mass (\%); SBY = Soybean biomass yield (kg dry matter ha $\left.{ }^{-1}\right)$; MBY $=$ Maize biomass yield $\left(\mathrm{kg}\right.$ dry matter ha $\left.{ }^{-1}\right)$; TBY $=$ Total biomass yield $\left(\mathrm{kg}\right.$ dry matter ha $\left.{ }^{-1}\right)$.

Dry matter loss and silage fermentation quality are directly related to the forage DM content at harvesting time. There was no difference to the maize silage dry mass (\%) with a mean value of $35.3 \%$ with lower and higher DM value of 33 and 37\%. According to Savoie and Jofriet (2003), silage DM content is the main driver to predict effluent losses and that effluent is prevented in most cases at DM content greater than $35 \%$. Intercrop row arrangements of $4 \mathrm{M}+4 \mathrm{~S}-30$ and $2 \mathrm{M}+2 \mathrm{~S}-45$ showed higher DM content for both maize and soybean. Closer maize plants at the 2 row maize and 4 rows aside may have affected species competition and light quality that may increase plant senescence and DM content in this treatment (Table 4).

It is worth to comment that in Brazil, there are many farmers that grow maize at $90 \mathrm{~cm}$ row spacing. In this case, a soybean row between maize may bring along some advantages to the system, such as land and natural resource use efficiency. According to Ren et al. (2016), land equivalent ratios (LER) of 0.84-1.35 indicated resource complementarity in most of the studied intercrops (maize + soybean). Complementarity was directly affected by changes in plant densities; the greatest LER were observed in 2 rows maize and 2 rows soybean intercrops at low density (45 thousand maize plant $\mathrm{ha}^{-1}$ ). Although, intercrops did not result in greater dry matter production than those of the higher producing maize sole crop ( 90 thousand maize plant ha ${ }^{-1}$ ) at any of the harvest indicating that maize had the growth advantage over soybean.

Salvagiotti et al. (2008) reported in a review article that biological $\mathrm{N}_{2}$ fixation (BNF) from soybean ranged from 0 up to $337 \mathrm{~kg} \mathrm{~N} \mathrm{ha}^{-1}$ and on average $50-60 \%$ of soybean $\mathrm{N}$ demand originates from BNF. Zimmer et al. (2016) reported soybean grain and protein yield per hectare of 2,455 and $965 \mathrm{~kg} \mathrm{ha}^{-1}$ (average from 2011 to 2013) with an average protein content of $386 \mathrm{~g} \mathrm{~kg}^{-1}$. These results highlight the soybean potential as a silage specie to be intercropped with maize. Moreover, effective inoculation with Bradyrhizobium strains increased grain yield, protein content and protein yield by up to $57 \%, 26 \%$ and $99 \%$, respectively and the percentage of nitrogen derived from air (Ndfa) ranged between $40 \%$ and $57 \%$.

Martin et al. (1998), evaluating different soybean maturing cultivars reported similar biomass yield between maize + soybean intercrops and maize monocrop. Furthermore, to the late soybean cultivar (was still green enough to be harvested with minimal pod shattering), land equivalent ratios revealed yield advantages of intercrops over monocrops of $21 \%$ and $10 \%$ for the shoot biomass and shoot protein yield, respectively. These aspects highlight the importance and viability of maize and soybean intercrop.

Soybean DM content ranged from 23 to $26 \%$. Low DM contents of soybeans may reflect lower quality of fermentation and stabilization of the silage process. According to Undersander et al. (2007) standing soybean forage at the R3 to R4 stage was generally at about $80 \%$ moisture and needed to be mowed and wilted to dry down to $65 \%$ moisture for ensiling. Another way to improve soybean silage fermentation process, is to intercrop it with maize, once the soluble carbohydrate content and the higher DM content contribute to the good 
fermentation process. Moreover, soybean (R3 stage) forage quality was similar to alfalfa haylage (Undersander et al., 2007).

Soybean silage harvested at the R2 and R4 stages showed various degrees of mold, with unpleasant odor and a dark green color tending black. The optimum time to harvest soybeans for silage is when seeds completely fill the pods and the lower leaves of the plant are just beginning to turn yellow (just before R7). At this point the field has achieved maximum dry matter yield and is beginning to decrease in moisture content. Soybeans harvested later will have higher oil content which reduces their ensiling characteristics (mixing grass at ensiling will help later harvested soybeans) (Undersander et al., 2007). At the experiment, soybean at the maize silage point was at the R5 stage.

Intercropped maize had a strong competitive effect on the growth of soybean at $2 \mathrm{M}+1 \mathrm{~S}-30$. A yield advantage in intercropping is achieved only when the component crops do not compete for the same resources in the same time and space. In the present study, the sharing of light by the component crops was important for improved utilization of resources, resulting in higher soybean yield of the intercropping system $2 \mathrm{M}+2 \mathrm{~S}-30 ; 4 \mathrm{M}+4 \mathrm{~S}-30$; $1 \mathrm{M}+2 \mathrm{~S}-30$ and $2 \mathrm{M}+2 \mathrm{M}-30$. Prasad and Brook (2005) reported that intercropping increased the total amount of radiation intercepted due to rapid establishment of ground cover by the combined canopies of the component crops.

Ren et al. (2016) reported greater Land Equivalent Ratio (LER) of maize in relation to soybean in the M2S2 and M4S2 intercrop, whereas the M2S4 intercrop had a higher partial LER for soybean than for maize. Thus, maize was dominant in the M2S2 and M4S2 cropping systems. These results are similar to the ones observed at this study. Plant density and relative frequency thus determined the relative yield contributions of maize and soybean in the intercrops.

To the maize dry matter biomass yield (MBY), there was no statistical differences between the evaluated arrangements, showing a mean value of $21,368 \mathrm{~kg} \mathrm{ha}^{-1}$. When compared to the maize sole crop $\left(23,368 \mathrm{~kg} \mathrm{ha}^{-1}\right)$, treatment 3M+3S-30 and 1M+2S-30 showed lower values (20,461 and 20,187 kg ha ${ }^{-1}$, respectively) (Table 4).

Total dry biomass yield did not differ between the evaluated arrangements, with a mean value of $23,640 \mathrm{~kg} \mathrm{ha}^{-1}$. Maize monocrop also showed similar value $\left(23,239 \mathrm{~kg} \mathrm{ha}^{-1}\right)$ to the intercropped arrangement (Table 4).

Batista et al. (2017) evaluating maize + soybean intercrop (1M+1S) reported similar biomass yield among intercrop and maize monocrop. Sánchez et al. (2010) reported that maize plants at border rows showed higher dry mass biomass, which turns out in similar yield of maize monocrop.

Research has indicated that the addition of soybean biomass to maize silage increases the crude protein content of the silage (Lempp et al., 2000). In this context, it is suggested that intercropping of maize + soybean considers the arrangements where higher soybean biomass occurs.

\subsection{Bromatological Traits of Maize+Soybean Silage}

There were differences among soybean biomass percentage in the total silage biomass. For most of the arrangements, soybean contributed with more than $10 \%$ of the total biomass, although, treatments $1 \mathrm{M}+1 \mathrm{~S}-30$, 2M+1S-30 and 1M+1S-45 showed lower values (Table 5). Results resemble those reported by Sánchez et al. (2010) in a two-year study. 
Table 5. Bromatological traits of maize+soybean silage grown under different row arrangements. UTFPR, Dois Vizinhos-PR, Brazil (2018)

\begin{tabular}{|c|c|c|c|c|c|c|c|c|}
\hline Treatments & PSS & $\mathrm{pH}$ & Ashes & NDF & ADF & TDN & SCP & TCPY \\
\hline $1 \mathrm{M}+1 \mathrm{~S}-30$ & $7.40 \mathrm{~b}$ & $4.40^{\mathrm{ns}}$ & $4.02^{\mathrm{ns}}$ & $36.14^{\mathrm{ns}}$ & $21.64^{\mathrm{ns}}$ & $72.69^{\mathrm{ns}}$ & $92.00^{\mathrm{ns}}$ & $2,209.39 \mathrm{~b}^{\mathrm{ns}}$ \\
\hline $2 \mathrm{M}+2 \mathrm{~S}-30$ & $10.32 \mathrm{a}$ & $4.38^{\mathrm{ns}}$ & $4.50^{\mathrm{ns}}$ & $39.30^{\mathrm{ns}}$ & $21.81^{\mathrm{ns}}$ & $72.57^{\mathrm{ns}}$ & $95.82 *$ & $2,382.35 \mathrm{a}^{*}$ \\
\hline $3 \mathrm{M}+3 \mathrm{~S}-30$ & $9.83 \mathrm{a}$ & $4.40^{\mathrm{ns}}$ & $4.25^{\mathrm{ns}}$ & $38.68^{\mathrm{ns}}$ & $19.89^{\mathrm{ns}}$ & $73.91^{\mathrm{ns}}$ & $95.28^{\mathrm{ns}}$ & $2,155.57 b^{\text {ns }}$ \\
\hline $4 \mathrm{M}+4 \mathrm{~S}-30$ & $12.20 \mathrm{a}$ & $4.46^{*}$ & $4.32^{\mathrm{ns}}$ & $38.83^{\mathrm{ns}}$ & $18.50^{\mathrm{ns}}$ & $74.88^{\mathrm{ns}}$ & $102.87^{*}$ & $2,563.53 \mathrm{a}^{*}$ \\
\hline $1 \mathrm{M}+2 \mathrm{~S}-30$ & $11.97 \mathrm{a}$ & $4.41^{\mathrm{ns}}$ & $4.40^{\mathrm{ns}}$ & $41.64^{\mathrm{ns}}$ & $20.17^{\mathrm{ns}}$ & $73.72^{\mathrm{ns}}$ & $96.58^{*}$ & $2,213.83 b^{\text {ns }}$ \\
\hline $2 \mathrm{M}+1 \mathrm{~S}-30$ & $6.14 \mathrm{~b}$ & $4.39^{\mathrm{ns}}$ & $3.78^{\mathrm{ns}}$ & $38.38^{\mathrm{ns}}$ & $20.30^{\text {ns }}$ & $73.63^{\mathrm{ns}}$ & $89.05^{\mathrm{ns}}$ & $1,963.45 b^{\mathrm{ns}}$ \\
\hline $1 \mathrm{M}+1 \mathrm{~S}-45$ & $7.76 \mathrm{~b}$ & $4.38^{\mathrm{ns}}$ & $4,22^{\mathrm{ns}}$ & $37.45^{\mathrm{ns}}$ & $18.79^{\mathrm{ns}}$ & $74.69^{\mathrm{ns}}$ & $91.69^{\mathrm{ns}}$ & $2.122,61 \mathrm{~b}^{\mathrm{ns}}$ \\
\hline $2 \mathrm{M}+2 \mathrm{~S}-45$ & $11.09 \mathrm{a}$ & $4.43^{\mathrm{ns}}$ & $4,24^{\mathrm{ns}}$ & $36.25^{\mathrm{ns}}$ & $19.06^{\mathrm{ns}}$ & $74.50^{\mathrm{ns}}$ & 98.99* & $2.409,41 \mathrm{a}^{*}$ \\
\hline Mean & 9.59 & 4.41 & 4.22 & 38.34 & 20.02 & 73.83 & 95.28 & 2.25252 \\
\hline $\mathrm{P}$ & 0.0000 & 0.2801 & 0.9300 & 0.6074 & 0.7735 & 0.7735 & 0.3539 & 0.0292 \\
\hline $\mathrm{CV}$ & 14.53 & 1.16 & 18.54 & 10.50 & 16.35 & 3.10 & 8.53 & 10.11 \\
\hline M-60 & $* *$ & 4.36 & 4.16 & 34.47 & 17.37 & 75.68 & 84.17 & $1,957.36$ \\
\hline
\end{tabular}

Note. ANOVA: $\mathrm{P}>0.05=$ not significant; $0.05 \geq \mathrm{P} \geq 0.01=$ significant at $5 \% ; \mathrm{P}<0.01=$ significant at $1 \%$. Tukey Test: In each column, averages followed by different lowercase letter differ in 5\% of probability. Test T: ${ }^{\mathrm{ns}}=$ Nonsignificant; $*=$ Significant at the $\mathrm{p} \leq 0.05$ level; $* *=$ The 0 (zero) values to the M- 60 , test $\mathrm{T}$ is not applied. Percentage of dry mass of soybean in silage (PSS) (\%), Potential hydrogen (pH), Ashes (\%), Neutral detergent fiber (NDF) (\%), Acid detergent fiber (ADF) (\%), Total digestible nutrients (TDN) (\%), Silage crude protein $(\mathrm{SCP})\left(\mathrm{g} \mathrm{Kg}^{-1}\right)$, Total crude protein yield (TCPY) $\left(\mathrm{Kg} \mathrm{ha}^{-1}\right)$.

Percentage of dry mass of soybean in silage (PSS) increased as soybean biomass increased. Thus, according to Stella et al. (2016) it may increase the quality of the silage.

Silage fermentation and the resulting $\mathrm{pH}$ primarily suppress the growth of other anaerobic microorganisms, $\mathrm{pH}$ being a good silage quality parameter. The growth of yeasts and other spoilage (aerobic) microorganisms may occur when silage $\mathrm{pH}$ reaches values higher than 4.5 (Muck, 2010). Maize+soybean silage showed $\mathrm{pH}$ values below 4.5, what suggests good silage fermentation and storage potential, even with soybean values reaching $12 \%$ of total biomass. Maize monocrop $\mathrm{pH}$ values were lower than the $4 \mathrm{M}+4 \mathrm{~S}-30$ arrangement, which also showed the highest soybean dry matter biomass values $\left(3,045 \mathrm{~kg} \mathrm{ha}^{-1}\right)$ and PSS (12.2\%) (Table 4).

Erdal et al. (2016) reported that the increase in the number of soybean rows in the intercropping systems results in an increased biomass of the legume, raising the $\mathrm{pH}$ values from 4.0 at the maize monocrop to 4.6 and 5.3 when using 3M:1S and $2 \mathrm{M}: 2 \mathrm{~S}$ respectively. According to the researchers, this increase of $\mathrm{pH}$ negatively influences the quality of silage. Even so, the authors reported that silage quality at 3M:1S was superior to maize monocrop in terms of crude protein $(7.31 \%)$, neutral detergent fiber $(42.56 \%)$, acid detergent fiber $(25.81 \%)$, lactic acid $(4.71 \%)$ and acetic acid $(4.05 \%)$ concluding that $3 \mathrm{M}: 1 \mathrm{~S}$ row intercropped production system was a better alternative for silage than maize monocrop.

Regarding to the other silage traits such as ashes, neutral detergent fiber (NDF) (\%), acid detergent fiber (ADF) $(\%)$, and total digestible nutrients (TDN), they were similar among row arrangement tested, collaborating with Sánchez et al. (2010) who studying different row arrangements in maize + soybean intercropped during two agricultural years reported similar values to these traits.

It is possible to observe that as the soybean share in the silage increases; the crude protein content of the silage also increases, improving silage quality. It is observed in Table 5 that some arrangements $(2 \mathrm{M}+2 \mathrm{~S}-30$, $4 \mathrm{M}+4 \mathrm{~S}-30,1 \mathrm{M}+2 \mathrm{~S}-30$ and $2 \mathrm{M}+2 \mathrm{~S}-45)$ presented higher SCP values than sole corn crop silage (M-60) (84.17 $\mathrm{g}$ $\mathrm{Kg}$ of silage), possibly explained by the fact that these arrangements showed higher percentage of soybean biomass. These results corroborate with other scientific investigations (Erdal et al., 2016; Sánchez et al., 2010; Stella et al., 2016).

Total crude protein yield (TCPY) is a consequence of the maize + soybean total biomass yield per area and its nitrogen content. These factors contributed to the arrangement of $2 \mathrm{M}+2 \mathrm{~S}-30,4 \mathrm{M}+4 \mathrm{~S}-30$ and $2 \mathrm{M}+2 \mathrm{~S}-45$, which showed TCPY values of 2,382, 2,563 and 2,409 $\mathrm{kg} \mathrm{ha}^{-1}$, differing from the other arrangements and sole corn crop (M-60) (Table 5). These data is important once silage energy and protein yield per area is more important than the total biomass yield per area. 
According to Zhang et al. (2015), maize + soybean intercrop had significant advantage in yield, economy, land utilization ratio and reducing soil nitrate nitrogen $(\mathrm{N})$ accumulation, as well as better residual effect on the subsequent wheat (Triticum aestivum L.) crop when compared to maize sole crop. Among the reason used to explain these better performances, the authors mentioned that intercropping systems increased relative biomass of intercropped maize, due to promoted photosynthetic efficiency of border rows and $\mathrm{N}$ utilization during symbiotic period.

Crude protein value varies according to maize and soybean meal prices, however, crude protein cost from grain (maize + soybean) usually is above $1 \mathrm{US} \$$ per $\mathrm{kg}$ of protein. Considering the fact that the arrangements $4 \mathrm{M}+4 \mathrm{~S}-30,2 \mathrm{M}+2 \mathrm{~S}-45$, and $2 \mathrm{M}+2 \mathrm{~S}-30$, yielded 606,452 , and $425 \mathrm{~kg} \mathrm{CP} \mathrm{ha}^{-1}$ more than sole corn crop, it is possible to infer that these treatments resulted in higher economic gain per area. Furthermore, higher $\mathrm{CP}$ yield occurs mainly due to the soybean nitrogen biological fixation efficiency, what also turns out maize + soybean intercrop as a more sustainable way of production.

Furthermore, these results associated with the data reported in the literature serves as an incentive to maize + soybean intercrop adoption. However, it is important to observe which plant arrangement should be used, in such a way that they can associate a high accumulation of maize biomass, together with a high accumulation of soybean biomass (above 10\% of silage dry mass), in order to add crude protein per kilogram of silage and increase crude protein yield by area.

\subsection{Effect of Intercropping on Grain Yield}

There was no significant difference between row arrangements in intercropping and maize sole crop to the number of rows (NR), number of grain per row (NGR), number of grain per spike (NGS) (Table 6). Results corroborate Paz et al. (2017), who reported similar number of rows and the number of grains per spike of sole crop and maize intercroped with different legumes (Canavalia ensiformis L., Crotalaria juncea L., Stylozobium aterrimum L., Cajanus cajan L., Vigna unguiculata L.).

Table 6. Effect of maize + soybean intercropping on grain yield. UTFPR, Dois Vizinhos-PR, Brasil (2018)

\begin{tabular}{|c|c|c|c|c|c|c|}
\hline Treatments (arrangements) & NR & NGR & NGS & TWG & GY & GYPM \\
\hline $1 \mathrm{M}+1 \mathrm{~S}-30$ & $17.50^{\mathrm{ns}}$ & $36.10^{\mathrm{ns}}$ & $632.88^{\mathrm{ns}}$ & $362.78 b^{\text {ns }}$ & $12,741.61^{\mathrm{ns}}$ & $212.47^{*}$ \\
\hline $2 \mathrm{M}+2 \mathrm{~S}-30$ & $18.90^{\mathrm{ns}}$ & $38.70^{\mathrm{ns}}$ & $731.96^{\mathrm{ns}}$ & $390.32 \mathrm{a}^{\mathrm{ns}}$ & $12,451.47^{\mathrm{ns}}$ & $221.09^{\mathrm{ns}}$ \\
\hline $3 \mathrm{M}+3 \mathrm{~S}-30$ & $18.30^{\mathrm{ns}}$ & $37.30^{\mathrm{ns}}$ & $681.96^{\mathrm{ns}}$ & $362.95 \mathrm{~b}^{\mathrm{ns}}$ & $12,039.74^{\mathrm{ns}}$ & $204.89 *$ \\
\hline $4 \mathrm{M}+4 \mathrm{~S}-30$ & $18.60^{\mathrm{ns}}$ & $37.15^{\mathrm{ns}}$ & $690.00^{\mathrm{ns}}$ & $372.79 \mathrm{a}^{\mathrm{ns}}$ & $12,525.77^{\mathrm{ns}}$ & $219.94^{\mathrm{ns}}$ \\
\hline $1 \mathrm{M}+2 \mathrm{~S}-30$ & $17.80^{\mathrm{ns}}$ & $37.50^{\mathrm{ns}}$ & $666.96^{\mathrm{ns}}$ & $378.36 \mathrm{a}^{\mathrm{ns}}$ & $12,341.66^{\mathrm{ns}}$ & $219.88^{\mathrm{ns}}$ \\
\hline $2 \mathrm{M}+1 \mathrm{~S}-30$ & $18.60^{\mathrm{ns}}$ & $37.05^{\mathrm{ns}}$ & $689.98^{\text {ns }}$ & $372.44 \mathrm{a}^{\mathrm{ns}}$ & $13,310.71^{\mathrm{ns}}$ & $221.95^{\mathrm{ns}}$ \\
\hline $1 \mathrm{M}+1 \mathrm{~S}-45$ & $18.10^{\mathrm{ns}}$ & $35.25^{\mathrm{ns}}$ & $638.14^{\mathrm{ns}}$ & $348.38 \mathrm{~b}^{*}$ & $12,433.53^{\mathrm{ns}}$ & $209.15^{*}$ \\
\hline $2 \mathrm{M}+2 \mathrm{~S}-45$ & $17.60^{\mathrm{ns}}$ & $36.90^{\mathrm{ns}}$ & $649.52^{\mathrm{ns}}$ & $367.05 b^{\text {ns }}$ & $11,689.05^{*}$ & $202.32 *$ \\
\hline Mean & 18.18 & 37.00 & 672.68 & 369.38 & $12,441.69$ & 213.96 \\
\hline $\mathrm{P}$ & 0.3070 & 0.5281 & 0.1919 & 0.0072 & 0.5760 & 0.1279 \\
\hline $\mathrm{CV}$ & 5.00 & 5.78 & 7.79 & 3.47 & 8.43 & 5.41 \\
\hline M-60 & 18.50 & 38.25 & 705.28 & 379.04 & $13,208.56$ & 229.95 \\
\hline
\end{tabular}

Note. ANOVA: $\mathrm{P}>0.05=$ not significant; $0.05 \geq \mathrm{P} \geq 0.01=$ significant at $5 \% ; \mathrm{P}<0.01=$ significant at $1 \%$. Tukey Test: In each column, averages followed by different lowercase letter differ in $5 \%$ of probability. Test $\mathrm{T}$ : ${ }^{n s}=$ Nonsignificant; $*=$ Significant at the $\mathrm{p} \leq 0.05$ level. Number of rows (NR), number of grain per row (NGR), number of grain per spike (NGS), thousand-grain weight (g) and grain yield (GY-kg ha $\left.{ }^{-1}\right)$ and grain yield per plant maize (GYPM) (g).

According to Ren et al. (2016), plant density and sowing proportions significantly affected the interspecies dynamics of maize-soybean intercrops. A yield advantage in intercropping is achieved only when the component crops do not compete for the same resources in the same time and space. Maize was generally more growth efficient for biomass accumulation than soybean during the growth period and maize leaf area index increased as its density increased. However, stronger competitive effects of intercropped soybean on the growth of maize were observed as the proportion of soybean seed was increased at low maize cropping density. In the present study, the sharing of light by the component crops was important for improved utilization of resources, resulting in higher productivity of the intercropping system. 
In addition, soybean has a high efficiency in the use of atmospheric nitrogen via biological fixation (Hungria et al., 2001). Thus, it is thought that crops do not compete for $\mathrm{N}$, a fact that can justify similar maize yield components between plant arrangements and maize monocrop.

Considering that soybean crop is of interest to the grower when cultivated for silage in intercropping system with maize, it is worth noting that the soybean crop received fertilized just as maize did which may allow lower competition between species. However, when maize is designed for grain production, the non-fertilization $(\mathrm{P}, \mathrm{K})$ of soybean could favor a lesser development of soybean plants, thus contributing with less competition with maize.

It is possible to observe in Table 6, that the statistical analysis divided the row arrangements in four groups regarding the TWG, demonstrating that the soybean cultivation may have an effect on the maize TWG. Despite differences between the arrangements, it was found that only the arrangement $1 \mathrm{M}+1 \mathrm{~S}-45(348 \mathrm{~g})$ showed lower values of MMG in relation to M-60 (379 g). It is not possible to identify which factor contributed to the statistical difference between the values of TWG in the evaluated arrangements, requiring more research for this component.

There was similarity for grain yield $\left(\mathrm{GY}-\mathrm{kg} \mathrm{ha}^{-1}\right)$ and grain yield per plant (GYP) (g) between the evaluated arrangements, with a general average of $12.441 \mathrm{~kg} \mathrm{ha}^{-1}$ and $213 \mathrm{~g}$ respectively (Table 6). Although, intercrop arrangement $2 \mathrm{M}+2 \mathrm{~S}-45$ yielded $1,519 \mathrm{~kg} \mathrm{ha}^{-1}$ less grain than the maize monocrop (M-60). It is necessary to find a balance between soybean biomass yields and maize grain yield reduction as it is desired to increase soybean biomass to increase silage crude protein and in the other hand, it is wished to have maize grain yield maximized or soybean effect as low as possible, since its grain is the main energy source of maize silage.

Therefore, even though the statistical analysis does not indicate a difference between the evaluated arrangements, it can be inferred that there was crop competition between the different arrangements. Treatments with higher soybean forage yield and total forage production, as $2 \mathrm{M}+2 \mathrm{~S}-30 \mathrm{~cm}, 4 \mathrm{M}+4 \mathrm{~S}-30,1 \mathrm{M}+2 \mathrm{~S}-30$ showed maize grain yield reduction of 757,683 and $867 \mathrm{~kg} \mathrm{ha}^{-1}$ or $5.7 ; 5.1$ and $6.5 \%$ respectively in relation to the sole maize crop. It is important to highlight that the arrangement $2 \mathrm{M}+2 \mathrm{~S}-45$ yielded similar forage than arrangement mentioned before, but with higher effect over maize grain yield (Table 6) also noticeable by its lower grain yield per plant (GYP) in relation to maize monocrop.

Thus, crop arrangement $2 \mathrm{M}+1 \mathrm{~S}-30$ presented maize yield values numerically superior than maize monocrop and a soybean biomass yield of $1,354 \mathrm{~kg} \mathrm{ha}^{-1}$. Ren et al. (2016) reported that both maize and soybean produced slightly greater yield per plant in the intercrop treatment compared to the sole crop treatments and this fact was attributed to a significant water use advantage as a result of species complementary roots distribution. Interspecific interaction increases growth, nutrient uptake and yield of dominant species, but decreases growth and nutrient uptake of the subordinate species during the co-existence (Milkereit, 2016).

Further studies need to evaluate maize + soybean intercrop silage effect on animal yield potential. Thus, soybean intercropped with maize may have a positive impact on the next crop, and the measurement of this possible effect may offset maize grain yield reduction to a point where it is interesting to adopt the intercrop system. Moreover, intercrop under low nitrogen fertilization may show good yield results and might as well be evaluated.

\section{Conclusion}

Maize + soybean intercrop showed similar maize biomass yield among arrangements, however, $3 \mathrm{M}+3 \mathrm{~S}-30$ and $1 \mathrm{M}+2 \mathrm{~S}-30$ showed lower maize dry mass yield in relation to the sole maize crop, evidencing competition between the crops. Despite this difference, total biomass (corn + soybean) yield was similar among intercropping arrangements and these with sole maize crop. In the other hand, soybean biomass yield showed greater values at the $2 \mathrm{M}+2 \mathrm{~S}-30,4 \mathrm{M}+4 \mathrm{~S}-30,1 \mathrm{M}+2 \mathrm{~S}-30$ and $2 \mathrm{M}+2 \mathrm{~S}-45$ arrangements, which contributed with more than $10 \%$ of the total silage yield and also resulted in higher crude protein contents.

$2 \mathrm{M}+2 \mathrm{~S}-30$ and $4 \mathrm{M}+4 \mathrm{~S}-30$ intercrop arrangements increased the silage crude protein percentage and its yield per area with similar grain yield to the sole maize crop.

Maize grain yield was lower at the $1 \mathrm{M}+1 \mathrm{~S}-30,3 \mathrm{M}+3 \mathrm{~S}-30,1 \mathrm{M}+1 \mathrm{~S}-45$ and $2 \mathrm{M}+2 \mathrm{~S}-45$ arrangements when compared to the other arrangements and with sole maize crop.

\section{References}

Alms, J. (2015). Volunteer Glyphosate-Resistant Maize and Soybean Competition and Control. Retrieved from https://openprairie.sdstate.edu/etd/1752 
Alvares, C. A., Stape, J. L., Sentelhas, P. C., de Moraes, G., Leonardo, J., \& Sparovek, G. (2013). Köppen’s climate classification map for Brazil. Meteorologische Zeitschrift, 22(6), 711-728. https://doi.org/10.1127/ 0941-2948/2013/0507

Ankon. (2009). Technology method 2: Rapid determination of oil/fat utilizing high temperature solvent extraction. Macedon.

Baghdadi, A., Halim, R. A., Othman, R., Yusof, M. M., \& Atashgahi, A. R. M. (2016). Productivity, relative yield and plant growth of forage maize intercropped with soybean under different crop combination ratio. Legume Research, 39(4), 558-564.

Batista, V. V., Adami, P. F., Kwiecinki, D., Pellizzari, É. V., Fonseca, A. C., \& Camana, C. (2017). Rendimento e qualidade de silagem no consórcio de milho com soja. I Congresso Brasileiro de Sistema Integrados de Produção Agropecuária, Cascavel, Pr, Brazil.

Batista, V. V., Link, L., Giaretta, R., Silva, J. S., \& Adami, P. F. (2018). Componentes de rendimento e produtividade de híbridos de milho cultivados em safrinha. Pesquisa Aplicada \& Agrotecnologia, 11(2), 67-75.

Bhering, S. B., Santos, H. G., Bognola, I. A., Cúrcio, G. R., Carvalho Junior, W. D., Chagas, C. D. S., ... Silva, J. D. S. (2008). Mapa de solos do Estado do Paraná, legenda atualizada. Embrapa Florestas-Artigo em Anais de Congresso (ALICE). Congresso Brasileiro De Ciência Do Solo, 32, Fortaleza. O solo e a produção de bioenergia: Perspectivas e desafios. Anais... Viçosa, MG.

Borghi, E., \& Crusciol, C. A. C. (2007). Produtividade de milho, espaçamento e modalidade de consorciação com Brachiaria brizantha em sistema plantio direto. Pesquisa Agropecuária Brasileira, 163-171. https://doi.org/10.1590/S0100-204X2007000200004

Cruz, J. C. (2001). Cultivares de milho para silagem. Embrapa Milho e Sorgo-Artigo em Anais de Congresso (ALICE) (pp. 92-114). Congresso Nacional De Estudantes De Zootecnia, Viçosa, MG. Anais... Viçosa: Associação Mineira dos Estudantes de Zootecnia.

Dow Agrosciences. (2018). Retrieved from http://www.dowagro.com/pt-br/brasil/product-finder/sementes/ hibrido-de-milho

Erdal, S., Pamukcu, M., Curek, M., Kocaturk, M., \& Dogu, O. Y. (2016). Silage yield and quality of row intercropped maize and soybean in a crop rotation following winter wheat. Archives of Agronomy and Soil Science, 62(11), 1487-1495. https://doi.org/10.1080/03650340.2016.1153801

Evangelista, A. R., Abreu, J. G., Amaral, P. N. C., Pereira, R. C., Salvador, F. M., Lopes, J., \& Soares, L. Q. (2005). Composição bromatológica de silagens de sorgo (Sorghum bicolor (L.) MOENCH) aditivadas com forragem de leucina (Leucaena leucocephala (LAM.) DEWIT). Ciência Agrotecnica, 29(2), 429-435. Retrieved from http://www.scielo.br/pdf/cagro/v29n2/a22.pdf

Ferreira, D. F. (2008). SISVAR: Um programa para análises e ensino de estatística. Revista Symposium, 6(2), 36-41.

Ferreira, J. P., Rodrigues, R. A. F., Kaneko, F. H., Kappes, C., Arf, M. V., \& Goés, R. J. (2015). Características Agronômicas Do Milho Sob Arranjos Espaciais E Densidades De Plantas Em Região De Cerrado. Cultura Agronômica: Revista de Ciências Agronômicas, 24(1), 27-44.

Gao, Y., Duan, A., Qiu, X., Sun, J., Zhang, J., Liu, H., \& Wang, H. (2010). Distribution and use efficiency of photosynthetically active radiation in strip intercropping of maize and soybean. Agronomy Journal, 102(4), 1149-1157. https://doi.org/10.2134/agronj2009.0409

Hungria, M., Campo, R. J., \& Mendes, I. D. C. (2001). Fixação biológica do nitrogênio na cultura da soja. Embrapa Soja. Brasília, DF: Embrapa Cerrados.

IAPAR (Instituto Agronômico do Paraná). (2018). Médias históricas em estações do IAPAR. Retrieved from http://www.iapar.br/arquivos/Image/monitoramento/Medias_Historicas/Francisco_Beltrao.htm

INMET (Instituto Nacional de Meteorologia). (2018). Retrieved from http://www.inmet.gov.br/sonabra/pg_dsp DadosCodigo_sim.php?QTg0Mw

Kananji, G., Yohane, E., Siyeni, D., Mtambo, L., Kachulu, L., Chisama, B., Malaidza, H., Tchuwa F., \& Mulekano O. (2013). A guide to soybean production in Malawi. Department of Agricultural Research Services, Lilongwe. 
Latati, M., Bargaz, A., Belarbi, B., Lazali, M., Benlahrech, S., Tellah, S., ... Ounane, S. M. (2016). The intercropping common bean with maize improves the rhizobial efficiency, resource use and grain yield under low phosphorus availability. European Journal of Agronomy, 72, 80-90. https://doi.org/10.1016/ j.eja.2015.09.015

Lempp, B., Morais, M. G., \& Souza, L. C. F. (2000). Produção de milho em cultivo exclusivo ou consorciado com soja e qualidade de suas silagens. Arquivo Brasileiro de Medicina Veterinária e Zootecnia, 52(3). https://doi.org/10.1590/S0102-09352000000300013

Liu, X., Rahman, T., Yang, F., Song, C., Yong, T., Liu, J., ... Yang, W. (2017). PAR interception and utilization in different maize and soybean intercropping patterns. PLoS ONE, 12(1), e0169218. https://doi.org/10.1371/ journal.pone.0169218

Martin, R. C., Astatkie, T., \& Cooper, J. M. (1998). The effect of soybean variety on maize-soybean intercrop biomass and protein yields. Canadian Journal of Plant Science, 78(2), 289-294. https://doi.org/10. 4141/P97-030

Mendes, W. S., Silva, I. J., Fontes, D. O., Rodriguez, N. M., Marinho, P. C., Silva, F. O., ... Silva, F. C. O. (2004). Composição química e valor nutritivo da soja crua e submetida a diferentes processamentos térmicos para suínos em crescimento. Arquivo Brasileiro de Medicina Veterinária e Zootecnia, 56(2), 207-213. https://doi.org/10.1590/S0102-09352004000200011

Milkereit, J. (2016). Plant Competitive Interactions Under Soil Nutrient Transport Limitation (Doctoral dissertation, Universität Zürich). https://doi.org/10.5167/uzh-126097

Muck, R. E. (2010). Silage microbiology and its control through additives. Revista Brasileira de Zootecnia, 39, 183-191. https://doi.org/10.1590/S1516-35982010001300021

Oliveira, I. L., Lima, L. M., Casagrande, D. R., Lara, M. A. S., \& Bernardes, T. F. (2017). Nutritive value of maize silage from intensive dairy farms in Brazil. Revista Brasileira de Zootecnia, 46, 494-501. https://doi.org/10.1590/s1806-92902017000600004

Paz, L. B. D., Gallo, A. D. S., Souza, R. D. L., Oliveira, L. V. N. D., Cunhav, C. D., \& Silva, R. F. D. (2017). Desempenho e produtividade do milho safrinha em consórcio com leguminosas em sistema orgânico. Revista de Ciências Agrárias, 40(4), 100-109. https://doi.org/10.19084/RCA16240

Pereira, L. C., Fontanetti, A., Batista, J. N., Galvão, J. C. C., \& Goulart, P. L. (2011). Comportamento de cultivares de milho consorciados com Crotalaria juncea: Estudo preliminar. Revista Brasileira de Agroecologia, 6(3), 191-200.

Prasad, R. B., \& Brook, R. M. (2005). Effect of varying maize densities on intercropped maize and soybean in Nepal. Experimental Agriculture, 41(3), 365-382. https://doi.org/10.1017/S0014479705002693

Ren, Y., Liu, J., Wang, Z., \& Zhang, S. (2016). Planting density and sowing proportions of maize-soybean intercrops affected competitive interactions and water-use efficiencies on the Loess Plateau, China. European Journal of Agronomy, 72, 70-79. https://doi.org/10.1016/j.eja.2015.10.001

Salvagiotti, F., Cassman, K. G., Specht, J. E., Walters, D. T., Weiss, A., \& Dobermann, A. (2008). Nitrogen uptake, fixation and response to fertilizer $\mathrm{N}$ in soybeans: A review. Field Crops Res., 108, 1-13. https://doi.org/10.1016/j.fcr.2008.03.001

Sánchez, D. G. R., Silva, J. E., Gil, A. P., Corona, J. S. S., Wong, J. A. C., \& Mascorro, A. G. (2010). Forage yield and quality of intercropped maize and soybean in narrow strips. Spanish Journal of Agricultural Research, 3, 713-721. https://doi.org/10.5424/sjar/2010083-1269

Santos, P. R. A., Chioderoli, C. A., Loureiro, D. R., de Araújo Nicolau, F. E., Oliveira, J. L. P., \& de Queiroz, R. F. (2017). Características morflógicas e produtivas do milho no consórcio com forrageiras em diferentes épocas de semeadura. Revista Brasileira de Agricultura Irrigada, 11(7), 2031. https://doi.org/10.712 7/rbai.v11n700678

Savoie, P., \& Jofriet, J. C. (2003). Silage storage. In D. R. Buxton, R. E. Muck, \& H. J. Harrison (Eds.), Silage Science and Technology (Agronomy Series No. 42, pp. 405-467). American Society of Agronomy, Madison.

Silva, D. V., Pereira, G. A. M., Freitas, M. D., Silva, A. D., Sediyama, T., Silva, G. S., ... Cecon, P. R. (2015). Produtividade e teor de nutrientes do milho em consórcio com braquiária. Ciência Rural, 45(8), 1394-1400. https://doi.org/10.1590/0103-8478cr20140760 
Silva, D., \& Queiroz, A. D. (2002). Análise de alimentos: Métodos químicos e biológicos (3rd ed.). Viçosa: UFV.

Stacciarini, T. D. C. V., de Castro, P. H. C., Borges, M. A., Guerin, H. F., Moraes, P. A. C., \& Gotardo, M. (2010). Avaliação de caracteres agronômicos da cultura do milho mediante a redução do espaçamento entre linhas e aumento da densidade populacional. Revista Ceres, 57(4). https://doi.org/10.1590/S0034-737 X2010000400012

Stella, L. A., Peripolli, V., Prates, Ê. R., \& Barcellos, J. O. J. (2016). Composição química das silagens de milho e sorgo com inclusão de planta inteira de soja. Boletim de Indústria Animal, 73(1), 73-79. https://doi.org/10.17523/bia.v73n1p73

Tedesco, M. J., Gianello, C., Bissani, C. A., Bohnen, H., \& Volkweiss, S. J. (1995). Análises de solo, plantas e outros materiais (Vol. 174). Porto Alegre: UFRGS.

Tropical Breeding and Genetics. (2017). Retrieved from http://www.tmg.agr.br/cultivar/tmg-7062-ipro

Undersander, D., Jarek, K., Anderson, T., Schneider, N., \& Milligan, L. (2007). A guide to making soybean silage. Forage and Grazinglands, 5(1). https://doi.org/10.1094/FG-2007-0119-01-MG

Yang, F., Liao, D., Wu, X., Gao, R., Fan, Y., Raza, M. A., ... Du, J. (2017). Effect of aboveground and belowground interactions on the intercrop yields in maize+soybean relay intercropping systems. Field Crops Research, 203, 16-23. https://doi.org/10.1016/j.fcr.2016.12.007

Zhang, Y., Liu, J., Zhang, J., Liu, H., Liu, S., Zhai, L., ... Yin, C. (2015). Row Ratios of Intercropping Maize and Soybean Can Affect Agronomic Efficiency of the System and Subsequent Wheat. PLoS ONE, 10(6), e0129245. https://doi.org/10.1371/journal.pone.0129245

Zimmer, S., Messmer, M., Haase, T., Piepho, H. P., Mindermann, A., Schulz, H., ... Heß, J. (2016). Effects of soybean variety and Bradyrhizobium strains on yield, protein content and biological nitrogen fixation under cool growing conditions in Germany. European Journal of Agronomy, 72, 38-46. https://doi.org/10.1016/ j.eja.2015.09.008

\section{Copyrights}

Copyright for this article is retained by the author(s), with first publication rights granted to the journal.

This is an open-access article distributed under the terms and conditions of the Creative Commons Attribution license (http://creativecommons.org/licenses/by/4.0/). 